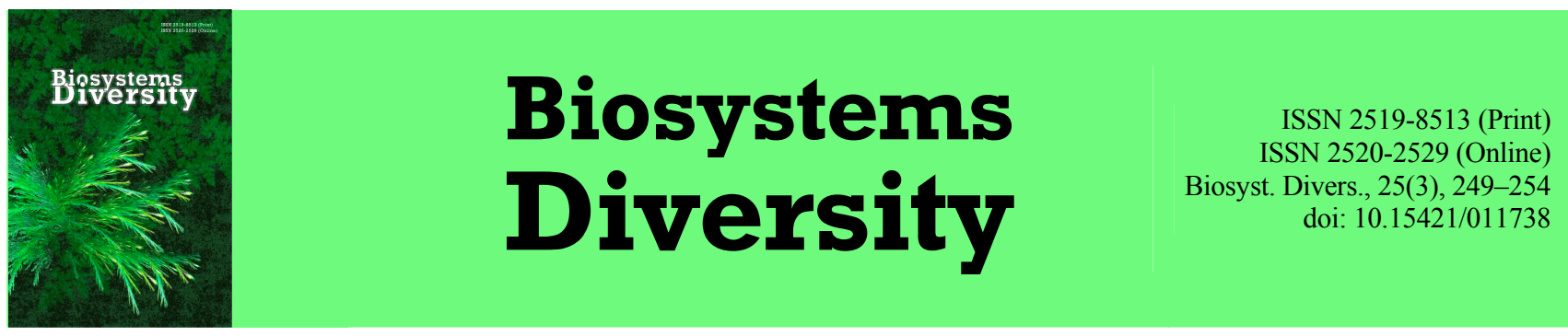

\title{
Dynamic growth model simulation for carbon stock management in dry forest
}

\author{
A. A. Almulqu \\ Kupang State Agricultural Polytechnic (Politani Kupang), East Nusa Tenggara, Indonesia
}

Article info

Received 19.07.2017

Received in revised form 14.08.2017

Accepted 17.08.2017

Kupang State Agricultural Polytechnic (Politani Kupang), East Nusa Tenggara, Indonesia. Tel: +62-821-101-078-39. E-mail:

ahmadalmulqu@yahoo.com

\begin{abstract}
Almulqu, A. A. (2017). Dynamic growth model simulation for carbon stock management in dry forest. Biosystems Diversity, 25(3), 249-254. doi:10.15421/011738

The model described in this article was simulated in order to provide the best recommendations related to the management of dry forest carbon stock. The methodology of this study is based to the dynamic growth model $\left(\mathrm{CO}_{2}\right.$ fix V3.1). The model was developed to calculate and estimate dry forest carbon fluxes and stocks. In this study the model was utilized for estimating how much carbon is sequestered in Diospyros celebica, Eucalyptus urophylla, Tectona grandis and mixed woods and soils. The results of this study show that in the 200 years simulated, total C stock had a tendency of increase. All of modules showed very similar patterns from 0 years to 40 years, except on bioenergy. Biomass had the highest value of carbon stock around $236.9 \mathrm{MGCHA}^{-1}$, carbon soil around $292.7 \mathrm{MGCHA}^{-1}$, product carbon storage around $226.8 \mathrm{MGCHA}^{-1}$ and bioenergy carbon storage presented a sustained increase and reached $522.3 \mathrm{MGCHA}^{-1}$ in the end of the simulated period. The contribution of the tree species component to total carbon stock was significantly positively correlated $\left(\mathrm{R}^{2}=0.634-0.882, \mathrm{P}<0.05\right)$ with the time simulated in years, except foliage of Diospyros celebica $\left(\mathrm{R}^{2}=0.301\right)$, foliage of Tectona grandis $\left(\mathrm{R}^{2}=0.162\right)$ and foliage of Eucalipthus urophylla $\left(\mathrm{R}^{2}=0.256\right)$. However, future studies should involve detailed examination on below-ground fraction and the effects of humans on global ecosystems.
\end{abstract}

Keywords: dynamic growth model; $\mathrm{CO}_{2}$ fix V3.1; carbon fluxes; biomass; simulated period

\section{Introduction}

About $40 \%$ of the earth's tropical and subtropical landmass is dominated by open or closed forest. Of this, $42 \%$ is dry forest, $33 \%$ is moist forest, and only $25 \%$ is wet and rain forest (Murphy and Lugo, 2007). Tropical dry forest is the most widely distributed landcover type in the tropics. As the rate of land-use/land-cover change from forest to pasture or agriculture accelerates worldwide, it is becoming increasingly important to quantify the ecosystem biomass and carbon (Jaramillo et al., 2003).

Careless management can result in significant degradation of vegetation and soil, leading to net carbon losses from the savannas into the atmosphere (Grace et al., 2006). Tropical forests are disappearing at an alarming rate of 13.5 million hectare per year globally (Kobayashi, 2004). Carbon dioxide is increasing in the atmosphere due to human activities (Emmerich, 2003). Disturbance in tropical forests includes individual tree processes, landscape level processes, and regional and climate influences. These processes and influences function on different temporal and spatial scales and are variable in the impact they have on tropical forests (Frolking et al., 2009).

The effect of greenhouse gases, especially $\mathrm{CO}_{2}$, on the warming of the atmosphere and the earth is of great importance. For this reason, studies are being conducted on certain measures such as limiting emissions in order to reduce the amount of $\mathrm{CO}_{2}$ in the atmosphere. Forest ecosystems have a significant potential in this respect. Carbon can be stored in the biomass, soil, litter, and coarse woody debris pools in forest ecosystems (Tolunay, 2011). With deforestation and land use change occurring throughout the tropics, improved understanding of these dynamic and complex forests are vital for the development of regional and global carbon budgets (Werth and Avissar, 2002).

According to Worku and Soromessa (2015), estimation of forest biomass is the most accurate and economical way of studying the change in carbon stocks. Studying carbon stocks has the capacity to measure the amount of carbon which accumulated in any specific forest. Moreover, estimates of biomass are required for assessing the amount of primary energy obtainable from the forests as an alternative to fossil fuels.

For scientific purposes, standing biomass is a fundamental state variable in several ecological and ecophysiological models (Zianis and Mencuccini, 2004). The above-ground biomass consists of stem, branch, and leaf biomass, and the below-ground biomass consists of prop roots and below-ground root biomass (Komiyama et al., 2008). Forest vegetation and soils constitute a major terrestrial carbon pool with the potential to absorb and store carbon dioxide from the atmosphere. The $\mathrm{CO}_{2}$ source and sink dynamics as trees grow, die, and decay are subjected to disturbance and forest management (Kaul et al., 2010). They reduce the amount of $\mathrm{CO}_{2}$ in the atmosphere, and provide benefit to the global climate (Kort and Turnock, 1999), through the process called photosynthesis. This process is one of the media that carbon passes through in its life cycle and much of the carbon, almost half of the carbon they consumed, is stored in the tissues of a tree (Worku and Soromessa, 2015). Two of the most widely suggested options to sequester carbon in drylands are afforestation (tree planting) and rangeland restoration through grazing exclusion. Ecosystems sequester carbon when their uptake increases and/or their losses decrease (Nosetto et al., 2006).

Rapid, easily implemented methods are needed for the assessment of standing biomass in order to estimate the carbon sequestration by forest ecosystems (Zianis and Mencuccini, 2004). Measurement and calculation of carbon stocks in soil and vegetation of tropical forests should be done accurately to anticipate carbon trading (Suwarna et al., 2012), and is essential to adaptive management under changing climate (Jia et al., 2014).

The carbon cycling in semiarid and arid areas remains largely unexplored, despite the wide distribution of drylands globally. Rehabilitation practices have been carried out in many desertified areas, but information on the $\mathrm{C}$ sequestration capacity of recovering vegetation is still largely lacking (Jia et al., 2014). 
This paper reports preliminary studies of Diospyros celebica, Eucalyptus urophylla, Tectona grandis and mixed forests to sequester carbon in dry forests of general throughout the world. In this study, we used a dynamic model $\left(\mathrm{CO}_{2} \mathrm{FIX}\right.$ version 3.1) of carbon storage in dry forests to investigate the carbon cycle of D. celebica, E. urophylla, $T$. grandis and mixed forests. The $\mathrm{CO}_{2} \mathrm{FIX}$ model has been tested and validated for the forest ecosystem in the Philippines, mixed pine-oak forest of central Mexico, multi-strata agroforestry system, tropical rainforest in Costa Rica, woodlots in Zambia (Kaonga and Smith, 2012) and farmland in Southwestern Ethiopia (Lemma et al., 2007). We avoided the abundant studies focused on fine litter dynamics or soil respiration, although these aspects of carbon cycling would be important for comprehensive review and site comparison of carbon budgets. This study did not examine remote sensing or modeling literature with regard to necromass, although these two approaches may provide fruitful means for estimation and understanding of necromass production and cycling (Frolking et al. 2009).

\section{Methodology}

The $\mathrm{CO}_{2}$ FIX stand level simulation model is a tool which quantifies the $\mathrm{C}$ stocks and fluxes in the forest biomass, the soil organic matter and the wood products chain. The model calculates the carbon balance with a time-step of one year. Basic input is stem volume growth and allocation pattern to the other tree compartments (foliage, branches and roots) (Schelhaas et al., 2004). The model is divided into three main parts: biomass, soil organic matter and products, and runs with time-steps of 1 year (Fig. 1).

The model produces output in tabular and graphic forms. It allows estimation of the time evolution of total carbon sequestered at the stand level. The total carbon stored in the forest stand at any time $\left(\mathrm{CT}_{\mathrm{t}}\right)$ is considered to be

$$
\mathrm{CT}_{\mathrm{t}}=\mathrm{Cb}_{\mathrm{t}}+\mathrm{Cs}_{\mathrm{t}}+\mathrm{Cp}_{\mathrm{t}}\left(\mathrm{TCHA}^{-1}\right) \text {, }
$$

where $\mathrm{Cb}_{\mathrm{t}}$ is the total carbon stored in living (above plus belowground) biomass at any time $\mathrm{t}$, in metric tonnes per hectare $\left(\mathrm{TCHA}^{-1}\right)$; $\mathrm{Cs}_{\mathrm{t}}$, the carbon stored in soil organic matter $(\mathrm{t} \mathrm{C} / \mathrm{ha})$, and $\mathrm{Cp}_{\mathrm{t}}$ is the carbon stored in wood products ( $\mathrm{TCHA}^{-1}$ ) (Masera et al., 2003).

The information on dry forest management practices for this study was synthesized from the literature. The dataset of management practices for model simulations consisted of carbon stock, wood density, current annual increment (CAI), growth correction factor, relative growth, mortality and product allocation for thinning harvesting. These kinds of information and their parameters used in $\mathrm{CO}_{2}$ FIX are listed in Table 1. In this study, thinning harvesting is one of silviculture treatment scenarios that was applied every 10 years and timber harvesting in year 40,80,120, 160 and 200 because this is one of strategies for increasing carbon sequestration (Moore et al., 2012).

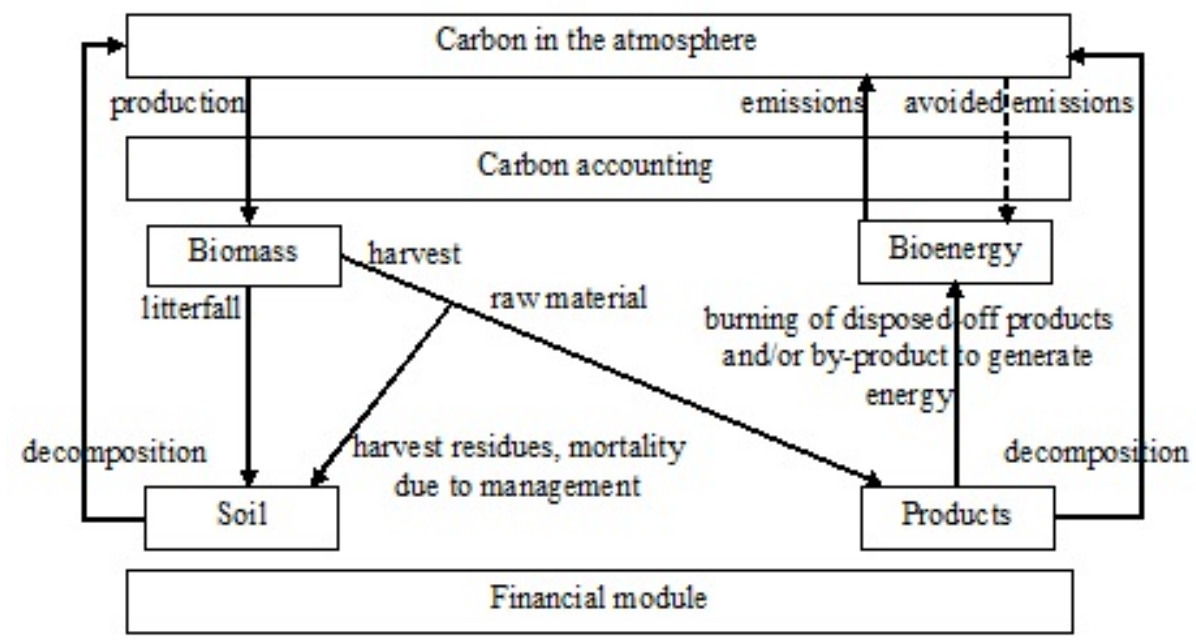

Fig. 1. The modules of $\mathrm{CO}_{2}$ FIX V 3.1 (Schelhaas et al., 2004)

Table 1

Summary of parameters used in simulating carbon dynamics of tree species

\begin{tabular}{lccccccccc}
\hline \multicolumn{1}{c}{ Species } & C & WD & Age & CAI & GF & Fo & Br & Ro & Mo \\
\hline Diospyros celebica & $0.46^{\mathrm{a}}$ & $1.09^{\mathrm{b}}$ & $20^{\mathrm{e}}$ & $0.50^{\mathrm{c}}$ & $1^{\mathrm{d}}$ & $0.44^{\mathrm{e}}$ & $0.21^{\mathrm{e}}$ & $0.54^{\mathrm{e}}$ & $0.028^{\mathrm{f}}$ \\
Eucalyptus urophylla & $0.46^{\mathrm{a}}$ & $0.55^{\mathrm{f}}$ & $20^{\mathrm{e}}$ & $28.59^{\mathrm{g}}$ & $1^{\mathrm{d}}$ & $0.44^{\mathrm{e}}$ & $0.19^{\mathrm{e}}$ & $0.54^{\mathrm{e}}$ & $0.026^{\mathrm{e}}$ \\
Tectona grandis & $0.46^{\mathrm{a}}$ & $0.75^{\mathrm{b}}$ & $25^{\mathrm{d}}$ & $14.01^{\mathrm{h}}$ & $1^{\mathrm{d}}$ & $0.07^{\mathrm{d}}$ & $0.4^{\mathrm{d}}$ & $0.28^{\mathrm{d}}$ & $0.026^{\mathrm{f}}$ \\
Mixed woods & $0.46^{\mathrm{a}}$ & $0.56^{\mathrm{i}}$ & $20^{\mathrm{e}}$ & $0.035^{\mathrm{j}}$ & $1^{\mathrm{d}}$ & $0.44^{\mathrm{e}}$ & $0.19^{\mathrm{e}}$ & $0.54^{\mathrm{e}}$ & $0.026^{\mathrm{e}}$ \\
\hline
\end{tabular}

Note: *C - carbon stock; WD - wood density; Age - species age; CAI - current annual increment; GF - growth correction factor; Fo - foliage; Br - branch; Ro - root; Mo - mortality; ${ }^{\mathrm{a}}$ - Hairiah et al. (2006); ${ }^{\mathrm{b}}$ - Martawijaya et al. (1992); ${ }^{\mathrm{c}}-$ Kinho et al. (2013); ${ }^{\mathrm{d}}-$ Permadi (2010); ${ }^{\mathrm{e}}-$ Ajit et al. (2013); ${ }^{\mathrm{f}}-$ Oliveira et al. (2014); ${ }^{\mathrm{g}}$ - Timander (2011); ${ }^{\mathrm{h}}$ - Bermejoa et al. (2004); ${ }^{\mathrm{i}}$ - IPCC (2003); ${ }^{\mathrm{j}}$ - Brown et al. (2002).

\section{Results}

Choice of rotation length and thinning intensity are commonly used to manage timber yield and carbon stocks of forests. These management practices affect all forms of carbon stocks (i.e., tree, soil and wood products) (Kaul et al., 2010). In 200 years simulated, total $\mathrm{C}$ stock had a tendency of increase. All of carbon pools showed very similar patterns from 0 years to 40 years, except on bioenergy. Biomass had the highest value at ages 40, 80,120, 160 and 200 years with $236.89 \mathrm{MGCHA}^{-1}$, soil at ages $40,80,120,160$, 200 years with $235.34,259.05,272.92,283.56,292.67 \mathrm{MGCHA}^{-1}$, product at ages $40,80,120,160,200$ with $140.39,177.91,200.37$, 215.64, 226.75 $\mathrm{MGCHA}^{-1}$ and bioenergy C storage presented a sustained increase and reached 522.25 $\mathrm{MGCHA}^{-1}$ in the end of the simulated period (Fig. 2).

Simulated carbon stock sequestration differed between the tree species, but the same pattern in each time of simulation $(40,80$, 120,160 and 200). Total carbon stock was increased until the end of the period of simulation. The averages of carbon stock sequestered at time of simulation was $231.85,75.50,7.26,0.73$ and 315.34 $\mathrm{MGCHA}^{-1}$ under E. urophylla, T. grandis, D. celebica, mixed woods and total carbon stock, respectively (Fig. 3).

The soil carbon under all species is expected to increase from 0 to $292.67 \mathrm{MGCHA}^{-1}$ for the 200 year simulation. The soil carbon in E. urophylla during the study period followed the same relative pattern as $T$. grandis. The measured carbon stock decreased with 
time of simulation (Fig. 4). All of the species components showed different contributions to total carbon stock. The contribution of the E. urophylla component in total carbon stock was $77.5 \%$ of stem, $8.4 \%$ of foliage, $22.5 \%$ of branch and $27.4 \%$ of root; $T$. grandis: $41.3 \%$ of stem, $0.5 \%$ of foliage, $10.9 \%$ of branch and $7.7 \%$ of root; E. urophylla: $2.54 \%$ of stem, $0.28 \%$ of foliage, $0.58 \%$ of branch and $0.92 \%$ of root. However, the mixed wood component in total carbon stock was $0.05 \%$ of stem, $0.04 \%$ of foliage, $0.01 \%$ of branch and $0.13 \%$ of root (Fig. 5 ).

The contribution of the tree species components to total carbon stock was significantly positively correlated $\left(\mathrm{R}^{2}=0.634-0.882, \mathrm{P}<\right.$
$0.05)$ with the time simulated in years, except foliage of $D$. celebica $\left(\mathrm{R}^{2}=0.301\right)$, foliage of $T$. grandis $\left(\mathrm{R}^{2}=0.162\right)$ and foliage of E. urophylla $\left(\mathrm{R}^{2}=0.256\right.$ ) (Table 2$)$. The significance of the D. celebica, T. grandis components in the dry forest increased in the order: foliage biomass $(\mathrm{FB})<$ branch biomass $(\mathrm{BB})<$ stem biomass $(\mathrm{BB})<$ root biomass $(\mathrm{RB})$. The significance for the E. urophylla component to total carbon stock increased in the order: foliage biomass $(\mathrm{FB})<$ branch biomass $(\mathrm{BB})<$ stem biomass $(\mathrm{SB})<$ root biomass (RB). However, the mixed wood component significance increased in the order: stem biomass $(\mathrm{SB})<$ branch biomass $(\mathrm{BB})<$ root biomass $(\mathrm{RB})<$ foliage biomass $(\mathrm{FB})$.

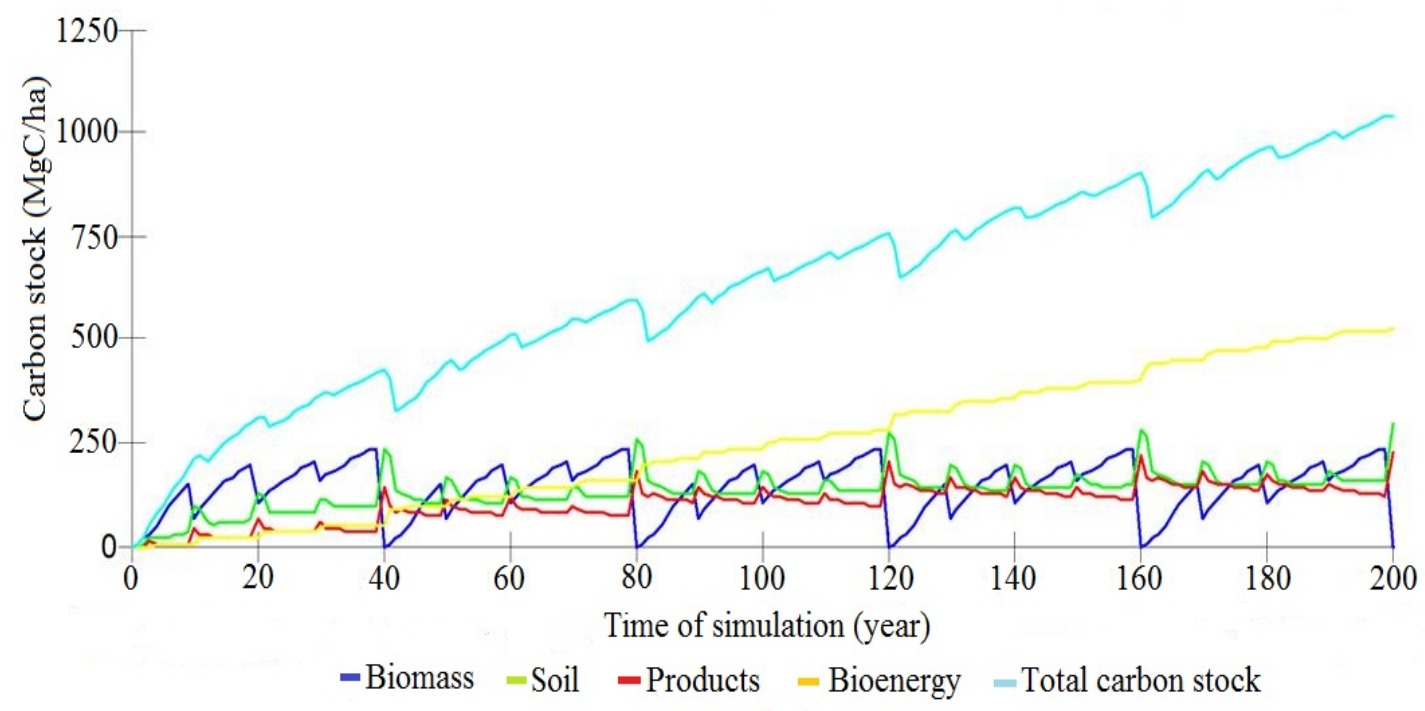

Fig. 2. Carbon sequestration dynamic of dry forest ecosystem over 200 years

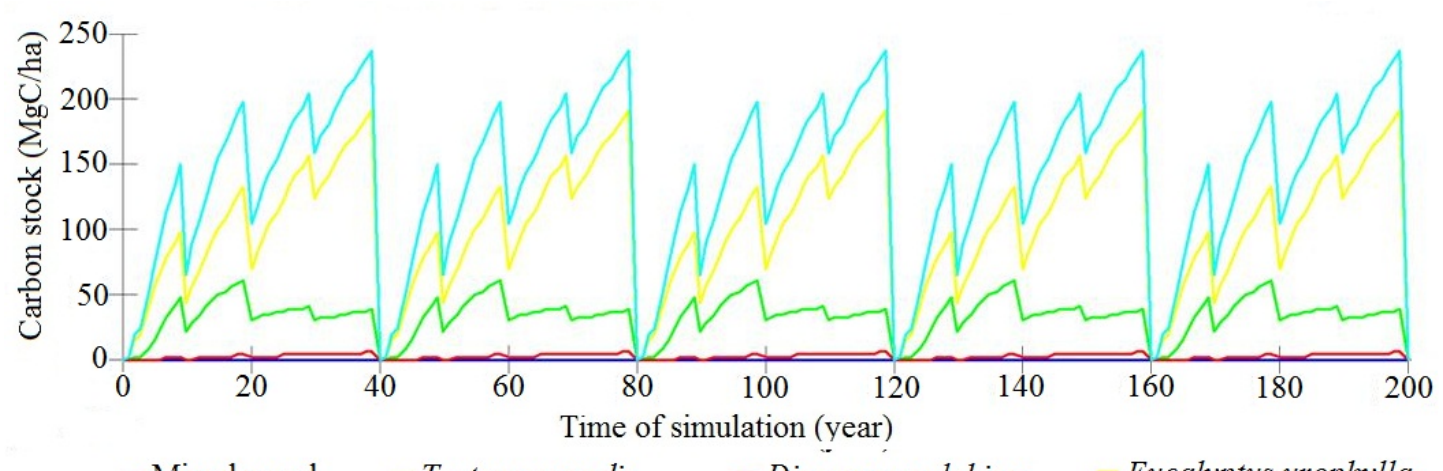

- Mixed wood - Tectona grandis - Diospyros celebica - Eucalyptus urophylla

- Total carbon stock

Fig. 3. Contribution of tree species to total carbon stock

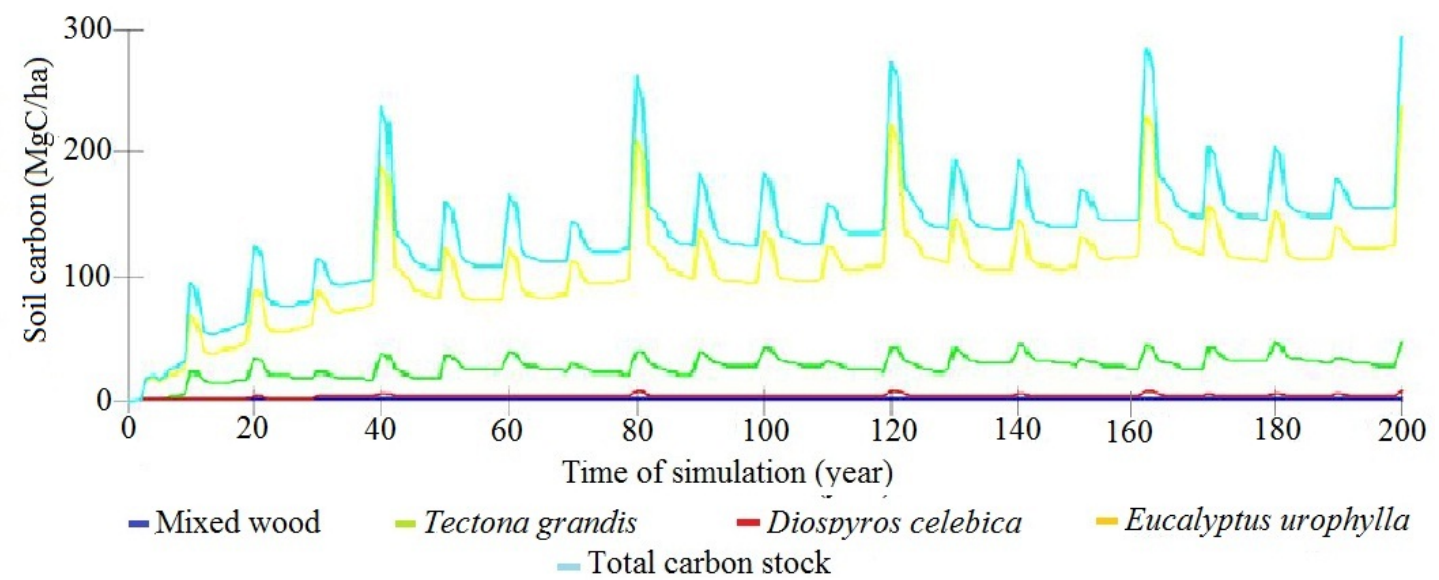

Fig. 4. Potential of soil carbon in each species areas 


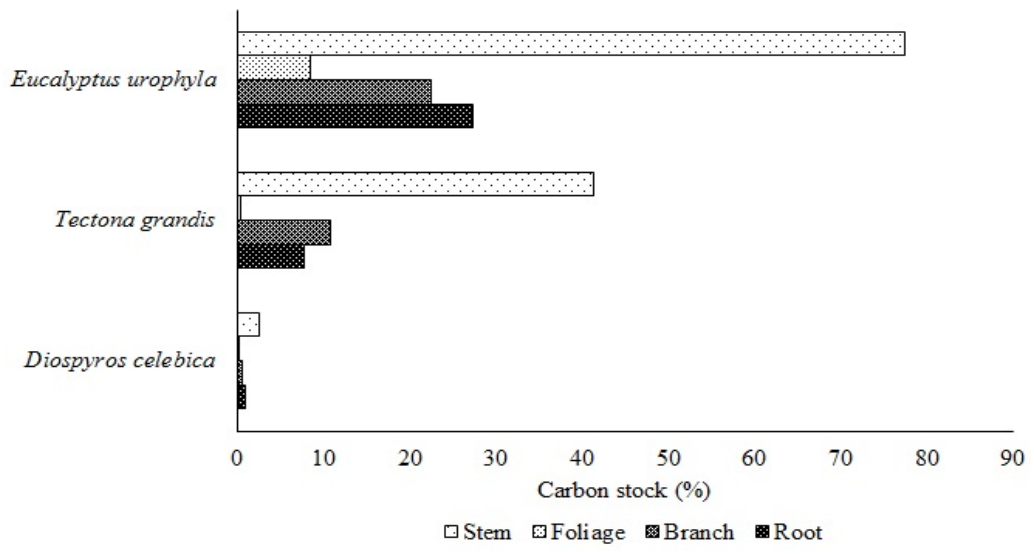

Fig. 5. Contribution of tree species components to total carbon stock (\%)

Table 2

Relationship between biomass of tree component to total carbon stock

\begin{tabular}{|c|c|c|}
\hline Species & Model of correlation & Significance $\left(\mathrm{R}^{2}\right)$ \\
\hline \multirow{4}{*}{$\begin{array}{l}\text { Diospyros } \\
\text { celebica }\end{array}$} & Cstock $=3.548 \ln (\mathrm{SB})+3.093$ & 0.783 \\
\hline & Cstock $=3.566 \ln (\mathrm{FB})+10.786$ & 0.301 \\
\hline & Cstock $=2.299 \ln (\mathrm{BB})+8.820$ & 0.780 \\
\hline & Cstock $=3.710 \ln (\mathrm{RB})+6.360$ & 0.784 \\
\hline \multirow{4}{*}{$\begin{array}{l}\text { Tectona } \\
\text { grandis }\end{array}$} & Cstock $=33.373 \ln (\mathrm{SB})-51.140$ & 0.793 \\
\hline & Cstock $=12.978 \ln (\mathrm{FB})+93.846$ & 0.162 \\
\hline & Cstock $=21.704 \ln (\mathrm{BB})+26.737$ & 0.760 \\
\hline & Cstock $=22.001 \ln (\mathrm{RB})+33.894$ & 0.764 \\
\hline \multirow{4}{*}{$\begin{array}{l}\text { Eucalipthus } \\
\text { urophylla }\end{array}$} & Cstock $=101.600 \ln (\mathrm{SB})-241.340$ & 0.762 \\
\hline & Cstock $=89.897 \ln (\mathrm{FB})+11.3240$ & 0.256 \\
\hline & Cstock $=113.010 \ln (B B)-159.090$ & 0.634 \\
\hline & Cstock $=106.300 \ln (\mathrm{RB})-161.890$ & 0.767 \\
\hline \multirow{4}{*}{$\begin{array}{l}\text { Mixed } \\
\text { woods }\end{array}$} & Cstock $=0.499 \ln (\mathrm{SB})+1.524$ & 0.734 \\
\hline & Cstock $=0.893 \ln (\mathrm{FB})+3.805$ & 0.882 \\
\hline & Cstock $=0.628 \ln (\mathrm{BB})+2.436$ & 0.774 \\
\hline & Cstock $=0.512 \ln (\mathrm{RB})+1.960$ & 0.790 \\
\hline
\end{tabular}

Note: $\mathrm{SB}$ - stem biomass; FB - foliage biomass; $\mathrm{BB}$ - branch biomass; RB root biomass.

\section{Discussion}

The results indicate that among the species studied, E. urophylla has the highest potential to sequester carbon, followed by $D$. celebica plantations. E. urophylla had the highest carbon stock of all the species. Maybe D. celebica and other species have lower carbon stocks, because water deficits or drought can greatly influence the amount of foliage produced by a stand and consequently have a direct effect upon the fractional interceptance of radiation and thus, net carbon gain and the potential growth rate of the stand. During drier periods, reductions in available soil water result in closure of stomata, which in turn constrains growth of $P$. radiata and other conifers. While this response to water deficits helps conserve water by limiting evaporative losses, it also reduces carbon dioxide uptake, thereby reducing photosynthetic rate, tree growth and wood production. Many plant traits are related to water uptake including hydraulic conductance, resistance to embolism, leaf to root ratios and root distribution. Water deficits or drought can greatly influence the amount of foliage produced by a stand and consequently have a direct effect upon the fractional interceptance of radiation and thus, net carbon gain and the potential growth rate of the stand (Waghorn et al., 2015).

The distribution of precipitation inputs into different hydrological components of water-limited forest ecosystems determines water availability to trees and consequently forest productivity (Yaseef et al., 2009). This is because, low water availability may also limit ecosystem respiration by reducing root activity, suppressing microbial decomposition of organic matter and restricting the diffusion of extracellular enzymes and C substrates in the soil (Wang et al., 2014).
According to Baishya and Barik (2011), 50-60 cm tree diameter class contributed $27.8 \%$ to the total tree aboveground biomass, indicating the important role of this diameter class in carbon storage. The larger trees $(>60 \mathrm{~cm})$ contributed $15.8 \%$ to the total aboveground biomass. Thus, the large trees together accounted for more than $43 \%$ of the total carbon in the tree component. The percentage contribution in north India of total biomass in different components of understory vegetation showed about $55 \%$ in stem, $18 \%$ in branches, $8 \%$ in leaf, and $19 \%$ roots (Singh et al., 2011). Fine root production in tropical evergreen forest in India ranged from 1 to $1.17 \mathrm{MGHA}^{-1} \mathrm{YR}^{-1}$ (Vasalakshi, 1994)

In the central highlands of Ethiopia in Northern Shoa Zone, the volume of trimmed small branches had a critical role for determination of density, which was vital for estimation of the total biomass of Juniperus procera and Podocarpus falcatus. The most dominant component of $J$. procera and P. falcatus are the trunk and large branches which have $82.7 \%$ of the total biomass for both species (Worku and Soromessa, 2015).

Biomass contribution varied significantly in rotation length. The 40 years rotation length showed the maximum rate of $\mathrm{C}$ input in aboveground biomass. This is because the current annual increment (CAI) reaches the apex period at the age of 40 years and after that the CAI starts declining. It is the point where the CAI culminates and gives highest productivity. In forestry the point where the CAI graphs cross each other and then CAI starts declining is considered as a rotation determination point. The study revealed that at the age of 40 years the rate of input of $\mathrm{C}$ stock remained highest and then it starts declining (Fig. 2 and 3).

In India, aboveground biomass was $88 \%$ of the total (stem $28 \%$, branch $57 \%$ and leaf 3\%), indicating that allocation in the roots was below the average of $20 \%$ observed in most natural forests. This might be expected due to soil compactness and presence of "Kankar Pan" (a stony layer of $\mathrm{CaCO}_{3}$ gravels) in the subsoil. As a consequence, roots could not spread and proliferate freely (Singh et al., 2011). But, mature plants with well-developed roots exploit a greater soil volume. They can maintain more constant resource uptake and retention during inter-pulse periods, and their survival rates during inter-pulse (drought) times are thus higher (Zimmermann et al., 2010).

Plant litter inputs are the major pathway for the return of organic matter to the soil. In the $\mathrm{CO}_{2}$ Fix model, estimates of litter production were used to predict inputs of carbon from vegetation to soil. The measured aboveground litter fall was predominantly composed of leaves (needles) but some twigs also occurred (Lemma et al., 2007). Leaves are one of the most sensitive indices reflecting water deficits for plants and leaf water content directly reflects the water status in plants. Leaf water content decreased from $60 \%$ to $59 \%$ at suitable level, from $59 \%$ to $56 \%$ at medium-stressed level and from $59 \%$ to $52 \%$ at severe-stressed level, respectively. These results showed that during the experimental period from spring to autumn, poplar leaf water content decreased gradually with the season change. The lower 
the soil water content, the more the reduction (Liang et al., 2006). The simulated and measured values were in close agreement except for the lower simulated values under Eucalyptus. The lower model estimate for the Eucalyptus stand was related to its attainment of maximum CAI at an earlier age than the other trees and to the presence of some twigs in the measured litter fall (Lemma et al., 2007).

According to Fiorese and Guariso (2013), litter constraint limits the amount of harvested biomass and consequently limits the sequestration and substitution of carbon. If the litter constraint is removed, the estimated greenhouse gas reduction more than doubles (from 290 to $640 \mathrm{KT} \mathrm{CO}_{2} \mathrm{EQY}^{-1}$ ). The amount of harvested biomass increases from about 310 to 630 thousand $\mathrm{m}^{3}$. The decision to safeguard the forest ecosystem by guaranteeing a certain amount of litter quantity has therefore a strong consequence on forest management.

Carbon inputs to the soil via three litter compartments: coarse consisting of stemwood, fine consisting of branches and coarse roots, and non-woody consisting of foliage and fine roots. The rate of carbon input into each compartment is determined by the growth and turnover rates, as well as inputs arising from mortality and slash. Depending on its chemical composition, litter is partitioned into one of three subsequent compartments: soluble compounds, holocellulose, and lignin-like compounds. In addition to these compartments, there are two humus compartments, which receive inputs from the coarse woody litter as well as the faster decomposing compounds (Bailis, 2009).

In this study, data on nutrient content of D. celebica, E. urophylla, $T$. grandis and mixed wood litters showed that the lignin content of these litters does not vary significantly. Environmental controls on litter decomposition in terrestrial ecosystems are fundamentally related to differences in litter quality (e.g., element concentration in tissues) and local climate (temperature, precipitation). These two factors modulate microbial (and other decomposers) activity and thus mediate the processing of organic matter and the rates of internal ecosystem nutrient cycling (Aber et al., 1990). Tropical plants play a vital role in controlling nutrient losses. Plants act as source of nutrients (deposition of litter) and sink of nutrients by increasing nutrient sequestration when they are more available. Higher tree biomass could provide more litter, resulting in a positive relationship between biomass and nutrients; higher biomass could also be the result of more nutrient availability. Plants have the potential to affect nutrient levels, to which they respond (de Castilho et al., 2006).

Soil organic carbon (SOC) also plays a very significant role in the global carbon cycle, as it is the largest terrestrial carbon pool (Kaul et al., 2010). In this study, soil carbon is expected to increase from 0 to $292.67 \mathrm{MGCHA}^{-1}$ for the 200 year simulation. In global pattern, belowground biomass was $10-45 \mathrm{MGCHA}^{-1}$ for dry tropical forest and 11-135 $\mathrm{MGCHA}^{-1}$ for tropical wet forest (Murphy and Lugo, 1986b).

As comparision materials, in Mozambique, soil carbon dominated the total, contributing $76.2 \mathrm{TCHA}^{-1}(70 \%)$. Woody biomass totalled $33.3 \mathrm{TCHA}^{-1}(30 \%)$, dominated by tree biomass $(29.7 \mathrm{tC} / \mathrm{ha})$. The division between soil carbon and total carbon stocks in Nambia ( $70 \%$ in soil) is similar to the 60 percent for Malawian miombo (Ryan et al., 2010). In the forests of Turkey 2251.26 TG C was in 2004. Of that total carbon stock, $74.8 \%$ was in soil, $21.3 \%$ in living tree biomass, and 3.9\% in litter and dead wood (Tolunay, 2011). According to Magalhães and Seifert (2015), total tree biomass in mecrusse woodlands in Mozambique was approximately $25 \%$ higher than above ground biomass. The root system, stem, and crown observed biomass densities of 29.62, 84.57, and 36.55 $\mathrm{MGCHA}^{-1}$, respectively. Stem biomass density accounted for approximately $70 \%$ of aboveground biomass and $56 \%$ of the total tree biomass density.

Measuring the $\mathrm{CO}_{2}$ absorbed by plants can be identified by converting the carbon content obtained by a conversion factor of 3.67 obtained from the ratio of atomic and molecular weight (Agus et al., 2011). We can note (Fig. 5) that the greater biomass and carbon reserves of natural gas reserves of $\mathrm{CO}_{2}$ will also increase. It can be concluded that sample species have a great impact on carbon stocks and it shows how the carbon content changes with time. The simulati- ons indicate that the long-term total $\mathrm{CO}_{2}$ equivalent ranges from 0 to 3819.44 $\mathrm{MGCO}_{2}$ EQUIVALENTHA $^{-1}$.

To assess the potential of additional carbon sequestration by forest management as part of climate change mitigation strategies, it is necessary to understand the carbon storage in forest biomass, soil and wood products, and the interactions between these compartments. Forest management interferes with carbon storage through choice of rotation length, thinning intensity, stand density and spacing, and silvicultural practices such as coppicing and soil preparation etc., and may cause both increases and decreases in carbon stocks in forest biomass. For a proper evaluation of the potential for carbon storage, it is important to distinguish these options in relation to species and silvicultural treatment (Kaul et al., 2010).

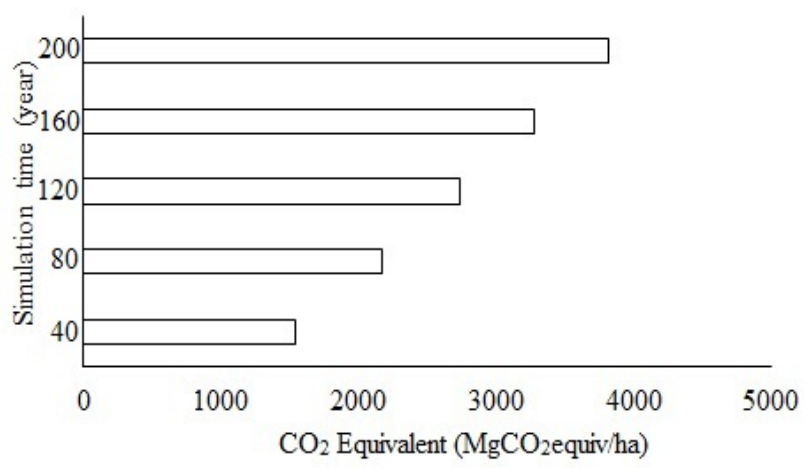

Fig. 5. $\mathrm{CO}_{2}$ equivalent of dry forest ecosystem in 200 years

Our estimate of carbon stock for all the species is highest at the rotation of 40 years because at this age, the rate of increment in the biomass of the tree is maximized and then gradually will decrease due to gradual decrease in CAI of tree biomass. For each sample of species it is possible to know the maximum capacity for absorbing carbon and its change with the time of simulation. Aboveground biomass and wood specific gravity are important parameters for characterizing forest ecosystems and they are needed to assess the limits to potential production of tropical forests (Mani and Parthasarathy, 2007). However, future studies should include detailed examination on each component of carbon fluxes, especially the dynamics of the below-ground fraction including fine-roots (Komiyama et al., 2008) and must be considered when attempting to understand, and eventually predict, the effects of humans on global ecosystems (Williams et al., 2005).

\section{References}

Aber, J. D., Melillo, J. M., \& McClaugherty, C. A. (1990). Predicting longterm patterns of mass loss, nitrogen dynamics, and soil organic matter formation from initial fine litter chemistry in temperate forest ecosystems. Journal of Botany, 68, 2201-2208.

Agus, F., Hairiah, K., \& Mulyani, A. (2001). Measuring carbon stock in peat soils. World Agroforestry Centre (ICRAF) Southeast Asia Regional Program, Indonesian Centre for Agricultural Land Resources Research and Development, Bogor, Indonesia.

Bailis, R. (2009). Modeling climate change mitigation from alternative methods of charcoal production in Kenya. Biomass and Bioenergy, 33, 1491-1502.

Baishya, R., \& Barik, S. K. (2011). Estimation of tree biomass, carbon pool and net primary production of an old-growth Pinus kesiya Royle ex. Gordon forest in North-Eastern India. Annals of Forest Science, 68, 727-736.

Bermejo, I., Cańellas, I., \& Miguel, A. S. (2004). Growth and yield models for teak plantations in Costa Rica. Forest Ecology and Management, 189, 97-110.

Brown, S., Phillips, H., Voicu, M., Abrudan, I., Blujdea, V., Pahontu, C., \& Kostyushin, V. (2002). Baseline report for romanian afforestation project: Prototype carbon fund. Romania Afforestation of Degraded Agricultural Land Project Baseline Study, Emission Reductions Projection and Monitoring Plans. World Bank.

de Castilho, C. V., Magnusson, W. E., de Arau'jo, R. N. O., Luiza o, R. C. C., Luizão, F. J., Lima, A. P., \& Higuchi, N. (2006). Variation in 
aboveground tree live biomass in a central Amazonian Forest: Effects of soil and topography. Forest Ecology and Management, 234, 85-96.

Emmerich, W. E. (2003). Carbon dioxide fluxes in a semiarid environment with high carbonate soils. Agricultural and Forest Meteorology, 116, 91-102.

Fiorese, G., \& Guariso, G. (2013). Modeling the role of forests in a regional carbon mitigation plan. Renewable Energy, 52, 175-182.

Frolking, S., Palace, M., Clark, D. B., Chambers, J. Q., Shugart, H. H., \& Hurtt, G. C. (2009). Forest disturbance and recovery - A general review in the context of space-borne remote sensing of impacts on aboveground biomass and canopy structure. Journal of Geophysic Restoration, 114, G00E02.

Grace, J., Jose, J. S., Meir, P., Miranda, H. S., \& Montes, R. A. (2006) Productivity and carbon fluxes of tropical savannas. Journal of Biogeography, 33, 387-400.

Jaramillo, V. J., Kauffman, J. B., Renteria-Rodriguez, L., Cummings, D. L., \& Ellingson, L. J. (2003). Biomass, carbon, and nitrogen pools in Mexican tropical dry forest landscapes. Ecosystems, 6, 609-629.

Jia, X., Zha, T. S., Wu, B., Zhang, Y. Q., Gong, J. N., Qin, S. G., Chen, G. P., Qian, D., Kellomäki, S., \& Peltola, H. (2014). Biophysical controls on net ecosystem $\mathrm{CO}_{2}$ exchange over a semiarid shrubland in northwest China. Biogeosciences, 11, 4679-4693.

Kaonga, M. L., \& Smith, T. B. P. (2012). Simulation of carbon pool changes in woodlots in eastern Zambia using $\mathrm{CO}_{2} \mathrm{FIX}$ model. Agrofororestry System, 86, 213-223.

Kaul, M., Mohren, G. M. J., \& Dadhwal, V. K. (2010). Carbon storage and sequestration potential of selected tree species in India. Mitigation Adaptation Strategy Global Change, 15, 489-510.

Kinho, J. (2013). Mengembalikan kejayaan eboni di Sulawesi Utara. Kementerian Kehutanan Badan Penelitian dan Pengembangan Kehutanan. Balai Penelitian Kehutanan, Manado (in Indonesian)

Kobayashi, S. (2004). Landscape rehabilitation of degraded tropical forest ecosystems. Case study of the CIFROR/Japan project in Indonesia and Peru. Forest Ecology and Management, 201, 13-22.

Komiyama, A., Ong, J. E., \& Poungparn, S. (2008). Allometry, biomass, and productivity of mangrove forests: A review. Aquatic Botany, 89, 128-137.

Kort, J., \& Turnock, R. (1999). Carbon reservoir and biomass in Canadian prairie shelterbelts. Agroforestry Systems, 44, 175-186.

Lemma, B., Kleja, D. B., Olsson, M., \& Nilsson, I. (2007). Factors controlling soil organic carbon sequestration under exotic tree plantations: A case study using the $\mathrm{CO}_{2}$ Fix model in Southwestern Ethiopia. Forest Ecology and Management, 252, 124-131.

Liang, Z., Yang, J., Shao, H., \& Hana, R. (2006). Investigation on water consumption characteristics and water use efficiency of poplar under soil water deficits on the Loess Plateau. Colloids and Surfaces B: Biointerfaces, 53, 23-28.

Magalhães, T. M., \& Seifert, T. (2015). Tree component biomass expansion factors and root-to-shoot ratio of Lebombo ironwood: Measurement uncertainty. Carbon Balance and Management, 10(9), 1-14.

Mani, S., \& Parthasarathy, N. (2007). Above-ground biomass estimation in ten tropical dry evergreen forest sites of peninsular India. Biomass and Bioenergy, 31, 284-290.

Masera, O. R., Caligaris, J. F. G., Kanninen, M., Karjalainen, T., Liski, J., Nabuurs, G. J., Pussinen, A., de Jong, B. H. J., \& Mohren, G. M. J. (2003). Modeling carbon sequestration in afforestation, agroforestry and forest management projects: The $\mathrm{CO}_{2} \mathrm{FIX}$ V.2 approach. Ecological Modelling, 164, 177-199.
Moore, P. T., DeRose, R. J., Long, J. N., \& Miegroet, H. V. (2012). Using silviculture to influence carbon sequestration in southern Appalachian spruce-fir forests. Forests, 3, 300-316.

Murphy, P. G., \& Lugo, A. E. (1986a). Ecology of tropical dry forests. Annual Review of Ecology, Evolution and Systematics, 17, 67-88.

Murphy, P. G., \& Lugo, A. E. (1986b). Structure and biomass of a subtropical dry forest in Puerto Rico. Biotropica, 18, 89-96.

Nosettoa, M. D., Jobbagya, E. G., \& Paruelo, J. M. (2006). Carbon sequestration in semi-arid rangelands: Comparison of Pinus ponderosa plantations and grazing exclusion in NW Patagonia. Journal of Arid Environments, 67, 142-156.

Oliveira, A. P. D., Schiavini, I., Vale, V. S. D., Lopes, S. D. F., \& Arantes, C. D. S. (2014). Mortality, recruitment and growth of the tree communities in three forest formations at the Panga Ecological Station over ten years (1997-2007). Acta Botanica Brasilica, 82(2), 234-248.

Ryan, C. M., Williams, M., \& Grace, J. (2010). Above- and belowground carbon stocks in a Miombo Woodland Landscape of Mozambique. Biotropica, 1-10.

Schelhaas, M. J., van Esch, P. W., Groen, T. A., de Jong, B. H. J., Kanninen, M., Liski, J., Masera, O., Mohren, G. M. J., Nabuurs, G. J., Palosuo, T.,

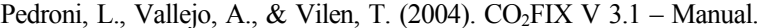
Alterra, Wageningen.

Singh, B., Tripathi, K. P., \& Singh, K. (2011). Community structure, diversity, biomass and net production in a rehabilitated subtropical forest in North India. Open Journal of Forestry, 1(2), 11-26.

Timander, P. (2011). Fertilization in Eucalyptus urophylla plantations in Guangxi, Southern China. Master Thesis. Swedish University of Agricultural Sciences.

Tolunay, D. (2011). Total carbon stocks and carbon accumulation in living tree biomass in forest ecosystems of Turkey. Turkey Journal Agriculture and Forestry, 35, 265-279.

Vasalakshi, N. (1994). Fine root dynamics in two tropical dry evergreen forest of Southern India. Journal Bioscience, 19, 103-116.

Waghorn, M. J., Whitehead, D., Watt, M. S., Mason, E. G., \& Harrington, J. J. (2015). Growth, biomass, leaf area and water-use efficiency of juvenile Pinus radiata in response to water deficits. New Zealand Journal of Forestry Science, 45(3), 1-11

Wang, B., Zha, T. S., Jia, X., Wu, B., Zhang, Y. Q., \& Qin, S. G. (2014). Soil moisture modifies the response of soil respiration to temperature in a desert shrub ecosystem. Biogeosciences, 11, 259-268.

Williams, J. W., Seabloom, E. W., Slayback, D., Stoms, D. M., \& Viers, J. H. (2005). Anthropogenic impacts upon plant species richness and net primary productivity in California. Ecology Letters, 8, 127-137.

Worku, E. \& Soromessa, T. (2015). Allometric equation for biomas determination in Juniperus procera Endl. and Podocarpus falcatus Mirb of wof-washa forest: Implication for climate change mitigation. American Journal of Life Sciences, 3(3), 190-202.

Yaseef, N. R., Yakir, D., Rotenberg, E., Schiller, G., \& Cohen, S. (2009). Ecohydrology of a semi-arid forest: Partitioning among water balance components and its implications for predicted precipitation changes. Ecohydrology, 1-12.

Zianis, D., \& Mencuccini, M. (2004). On simplifying allometric analyses of forest biomass. Forest Ecology and Management, 187, 311-332.

Zimmermann, J., Higgins, S., Grimma, V., Hoffmann, J., \& Linstädter, A. (2010). Grass mortality in semi-arid savanna: The role of fire, competition and self-shading. Perspectives in Plant Ecology, Evolution and Systematics, 12, 1-8. 